\title{
Impacts of Agriculture on the Environment and Soil Microbial Biodiversity
}

\author{
Adoración Barros-Rodríguez ${ }^{1}$, Pharada Rangseekaew ${ }^{2,3}$, Krisana Lasudee ${ }^{4}$, Wasu Pathom-aree ${ }^{4}$ (D) and \\ Maximino Manzanera $1, * \mathbb{D}$
}

1 Department of Microbiology, Institute for Water Research, University of Granada, 18071 Granada, Spain; dorybarros@ugr.es

2 Doctor of Philosophy Program in Applied Microbiology (International Program), Faculty of Science, Chiang Mai University, Chiang Mai 50200, Thailand; bee.pharada@gmail.com

3 Graduate School, Chiang Mai University, Chiang Mai 50200, Thailand

4 Research Center of Excellence in Bioresources for Agriculture, Industry and Medicine, Department of Biology, Faculty of Science, Chiang Mai University, Chiang Mai 50200, Thailand; krisanaba@gmail.com (K.L.); wasu215793@gmail.com (W.P.-a.)

* Correspondence: manzanera@ugr.es; Tel.: +34-958-248324; Fax: +34-958-243094

Citation: Barros-Rodríguez, A.;

Rangseekaew, P.; Lasudee, K.;

Pathom-aree, W.; Manzanera, M.

Impacts of Agriculture on the

Environment and Soil Microbial

Biodiversity. Plants 2021, 10, 2325.

https://doi.org/10.3390/

plants10112325

Academic Editor: Othmane Merah

Received: 7 September 2021

Accepted: 25 October 2021

Published: 28 October 2021

Publisher's Note: MDPI stays neutral with regard to jurisdictional claims in published maps and institutional affiliations.

Copyright: (c) 2021 by the authors. Licensee MDPI, Basel, Switzerland. This article is an open access article distributed under the terms and conditions of the Creative Commons Attribution (CC BY) license (https:/ / creativecommons.org/licenses/by/ $4.0 /)$.

\begin{abstract}
Agriculture represents an important mechanism in terms of reducing plant, animal, and microbial biodiversity and altering the environment. The pressure to cope with the increasing food demands of the human population has intensified the environmental impact, and alternative ways to produce food are required in order to minimize the decrease in biodiversity. Conventional agricultural practices, such as floods and irrigation systems; the removal of undesired vegetation by fires, tilling, and plowing; the use of herbicides, fertilizers, and pesticides; and the intensification of these practices over the last 50 years, have led to one of the most important environmental threats-a major loss of biodiversity. In this study, we review the impact that agriculture and its intensification have had on the environment and biodiversity since its invention. Moreover, we demonstrate how these impacts could be reduced through the use of microorganisms as biostimulants.
\end{abstract}

Keywords: biodiversity; agriculture; biostimulants; environmental threats

\section{Introduction}

Since the appearance of human beings 2.5 million years ago in East Africa, biodiversity has been declining. This decline was intensified with the invention of agriculture approximately 10,000 years ago, sharply reducing plants and animal biodiversity. In response to agricultural requirements, humans, through domestication, have caused animals and plants to evolve artificially [1]. Additionally, wild plants and animals in farming areas have been affected by the increase in food production; the diversity of these wild organisms has declined [2]. Growing domesticated species involves different cultivation conditions and techniques, such as the use of fertilizers, tillage, changes in land use, and the use of specific varieties of cultivated plants, all of which depend on the availability of natural resources and have resulted in a profound reduction in biodiversity [3]. The increase in food production was achieved as a result of these alterations. Owing to this increase, the human population also increased in number. Estimates suggest that since the appearance of humans, approximately 2.5 million years were needed to reach a population of between 1 and 10 million, which occurred before agriculture was invented. Thereafter, since the invention of agriculture, only 5000 years were needed to double that figure and reach a population of between 5 and 20 million $[4,5]$. This acceleration in population increase resulting from agriculture also implies that a continuous increase in agricultural production is required to meet the demands of the growing population. Therefore, a continuous increase in the area dedicated to agriculture is needed to cope with the growing food 
demands. Today, we estimate that the area dedicated to agriculture is in excess of $38 \%$ of the earth's surface [6]. An alternative solution is agricultural intensification, i.e., the increase in agricultural production per unit area through different farming techniques (Figure 1). However, agricultural intensification results in an additional loss of biodiversity. Agricultural expansion and intensification are together recognized as the key drivers of biodiversity loss in the 21st century [7].

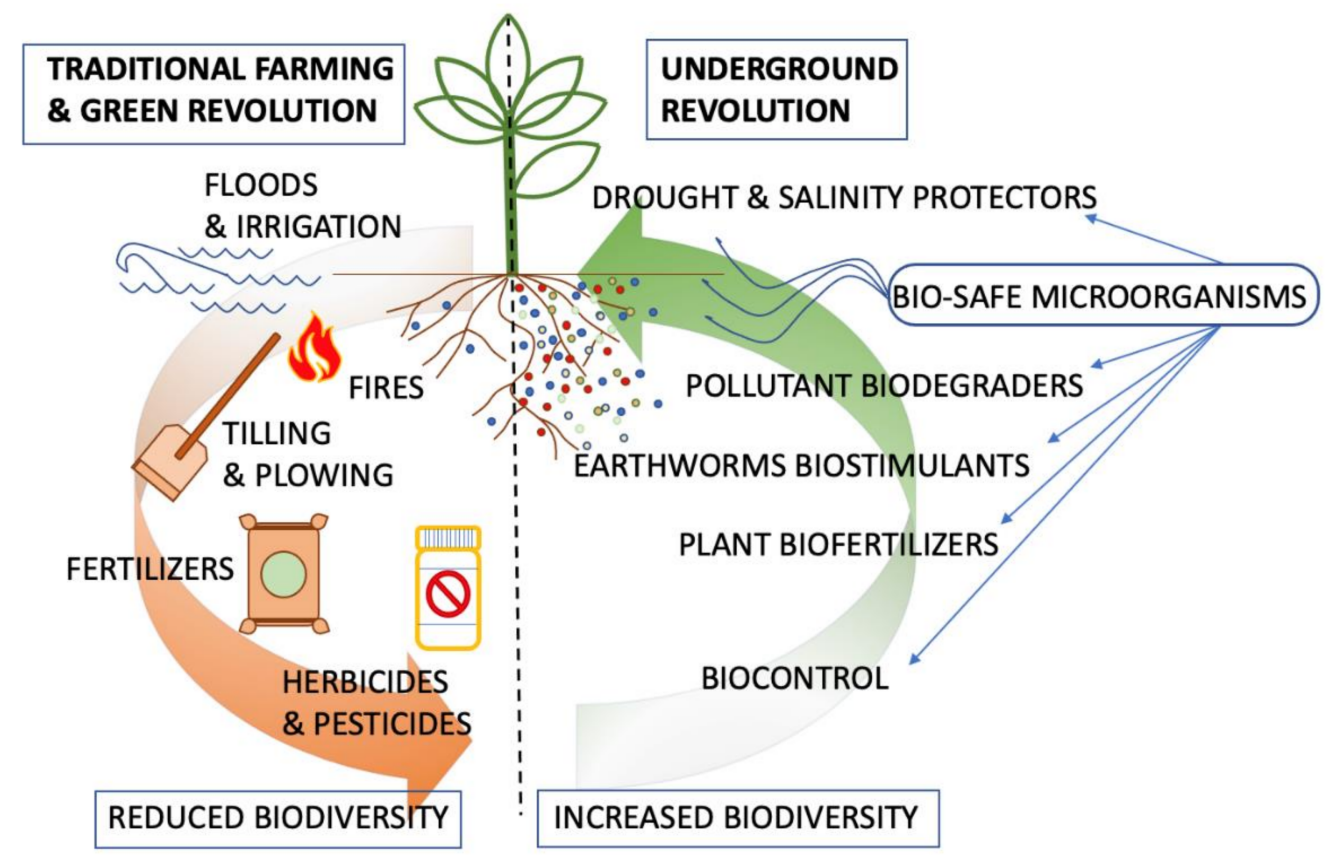

Figure 1. Conceptual diagram of traditional farming and Green Revolution, and Underground Revolution on soil microbial biodiversity. Colored dots represent microbial taxa.

Previous studies analyzed the impact of different agricultural practices on soil microbial biodiversity. In this work, we explored the impact that traditional practices have and compared them with the practices associated with the Green Revolution. In addition, we proposed a series of alternative practices based on the use of safe microorganisms in order to promote more sustainable agricultural practices and greater conservation of soil microbial biodiversity.

\section{The Impact of Traditional Agricultural Management and Techniques}

\subsection{Floods}

The origin of agriculture initially occurred near large rivers, such as the Euphrates, Tigris, Indus, and Huang He rivers, and on their floodplains. These areas are now home to nearly 2.7 billion people [8,9]. These rivers were associated with arid or semi-arid areas, and they caused floods that enriched the surrounding areas with nutrients present in the sediments (mostly nitrogen and phosphorous but also potassium, magnesium, sulfur, and calcium), making them suitable for cultivation. The increase in soil nutrients from the sediments from river floods results in increased soil microbial respiration, biomass, and enzyme activity [10]. Changes in the amount and type of decomposable nutrients and altered nitrogen fluxes affect plant growth and soil microbial biomass and biodiversity [11,12]. Floods also affect oxygen availability and, thus, in theory, create the ideal anaerobic conditions for switching an aerobic microbial community into a dominant anaerobic one [13]. In general, the microbial biomass is reduced after a flooding event, as was determined by Wagner et al. (2015). On the basis of the study of fatty acids, they observed a higher proportion of Gram-positive bacteria than Gram-negative bacteria in response to the flooding effect [14]. However, in the short term, the increased concentration of nutrients depends on the plant diversity of the area and the increased availability of nitrogen as a 
result of the flood. In areas with low plant diversity, typical in agriculture environments, these effects are more pronounced and higher alterations in biomass and soil microbial activity are found, improving crop production [10].

\subsection{Irrigation}

After achieving cultivation on riverbanks, expanding agriculture required an irrigation system that supplied water to plants that were farther from the river. To this end, irrigation systems were used, involving channels, ditches, and various water transport systems connected to the nearest river. Irrigation systems also alter ecosystems in a similar manner to floods, although the effects of irrigation on plants were mitigated by the use of furrows or ridges that prevented water from covering the plants. Regions in which rainwater is insufficient for agriculture, such as arid and semi-arid regions, depend on irrigation systems, and these have a substantial impact on soil microbiota. According to various studies, the continued use of irrigation in the cold desert sagebrush steppe resulted in a loss of soil nutrients; for example, a loss of up to $16 \%$ of the stored carbon and approximately one-third of the $\mathrm{NH}_{4}-\mathrm{N}$ was reported, as compared with non-irrigated soils. These changes in the soil's nutritional contents also affect the microbial (bacterial and fungal) community. Despite the nutrient reduction, microbial richness, evenness, and diversity generally increased with irrigation, most likely due to the increase in water availability [15].

Currently, various irrigation systems are associated with wastewater treatment plants, which result in an increase in the total nitrogen and organic matter in the soils. However, despite this increase in nutrients, the microbiota of these soils is reduced by the presence of certain pollutants, such as heavy metals, including mercury [16], and by the introduction of human-derived microorganisms.

\subsection{Fires}

After the success of agriculture on the margins of rivers, and after the invention of irrigation systems, agriculture was extended to zones previously occupied by forests. Large areas of forest were burned to cultivate domesticated plants and to create new grazing areas [17]. This technique is still in use today, with an estimated $7.2 \%$ of global forests having been lost since 2000. This is especially prevalent in tropical regions (mainly South America and Africa), where a $60 \%$ reduction in intact forest landscapes was observed between 2000 to 2013 [18]. This type of expansion also contributes to the loss of biodiversity. Specifically, fires cause an important loss of both plant and animal biodiversity, which profoundly affects the ecosystem. In addition, these fires generate changes in the chemical and physical properties of the soil, as a function of the fire severity and soil type [19]. These changes in the soil properties are caused by the heat generated, which induces chemical oxidation of soil organic matter, which, in turn, affects the microbial composition of the soil. This also occurs during wildfires [20]. Studies conducted in Mediterranean forests affected by fires showed that the fire had an impact on the bacterial communities involved in the nitrogen cycle, causing a loss of the diversity of the nif $\mathrm{H}$ gene, which codes for the enzyme nitrogenase reductase [21]. The effect on the nitrogen cycle depends on the type of plants present in the soil prior to the wildfire. Prendergast-Miller et al. demonstrated that ammonium is the dominant form of soluble nitrogen found in the soil when eucalyptus trees are burned. In contrast, nitrate becomes the dominant form of soluble nitrogen in the soil after the burning of pasture [22]. Alterations in the microorganisms involved in nitrogen metabolism were found in response to the altered nitrogen cycle. An increase in Actinobacteria and Firmicutes phyla in the soil was noted after a wildfire in a Mediterranean forest [23]. Actinobacteria, Proteobacteria, and Firmicutes phyla were detected after the wildfire in a eucalyptus forest [22]. Proteobacteria, Acidobacteria, and Actinobacteria phyla were identified after a wildfire in a northern boreal forest [24]. Numerous species of the Actinobacteria phylum have been described as having a high tolerance to abiotic stresses, 
such as heat and a lack of nutrients and drought; thus, it is normal to find this type of bacteria after a forest fire [25].

Fire is still used to remove slash, stubble, straw, and plant debris from previous harvests. This practice causes increased soil erosion, increases soil $\mathrm{pH}$, causes loss of nutrients, such as carbon, nitrogen, and sulfur, and, in general, results in a decrease in soil quality [26]. The burning of straw residues also pollutes the atmosphere, as it produces greenhouse gas emissions (including $\mathrm{CH}_{4}$ and $\mathrm{N}_{2} \mathrm{O}$ ) that exceed the Intergovernmental Panel on Climate Change (IPCC) default value [27]. Furthermore, this adversely affects the soil microbiota and, more specifically, plant growth-promoting rhizobacteria (PGPR) - a particular type of rhizobacteria from the area surrounding the root that improve plant growth [28].

\subsection{Tilling and Plowing}

Overturning the surface layers of the soil to eliminate weeds and other unwanted plants and seedbed preparation in the cropping area is an alternative to fire. This can be achieved by either tilling or plowing, both of which contribute to the aeration of the soil and mixing when fertilizers have been added. However, tillage and plowing also alter the biological and chemical characteristics of the soil and promote erosion by reducing soil moisture and organic matter contents $[29,30]$. Both techniques affect the population of earthworms (Lumbricidae) and soil microorganisms. Both earthworms and soil microorganisms have an important impact on the biological, chemical, and physical properties of the soil and affect its quality [31]. Earthworms represent the largest component of animal biomass in the soil, and they increase soil quality by improving its structure and increasing nutrient availability [32]. The control of plant pathogens, the production of PGPR, and the production of plant growth-regulating substances have been previously described [33]. According to a recent meta-analysis, earthworms contribute to nutrient availability by releasing their casts, which contain higher phosphorus $(84 \%)$, nitrogen (24\%) [34] and organic carbon (an average of over 40-48\%) than bulk soil. However, conventional tilling and plowing techniques markedly reduce the earthworm population, with immature worms, which make up $76-90 \%$ of the population, being particularly affected $[35,36]$. The adverse impact that tilling and plowing have on earthworms depends on the soil texture and climate conditions.

Zuber and Villamil described the negative impact that tillage has on soil microbial biodiversity and enzyme activity using a meta-analysis based on 139 observations [37]. Loss of moisture, changes in temperature, alterations to soil microclimatic factors, and access to organic matter all influence microbial communities [38]. Soil organic matter dynamics profoundly depend on microbial abundance and diversity $[39,40]$. NavarroNoya et al. described the alterations in the bacterial community caused by tillage, and more specifically, alteration in Actinobacteria, Betaproteobacteria, and Gammaproteobacteria. In this study, the proportion of Betaproteobacteria was correlated with electrolytic conductivity and clay content, while the proportion of Gammaproteobacteria was correlated with the total organic carbon [39].

\subsection{Fertilizers}

Another milestone in the history of agriculture is the use of fertilizers. These compounds, initially of organic nature, came from domesticated animal dung or bird guano. Soil concentrations of certain chemical elements increased with the addition of fertilizers, helping crop plant growth. The most common elements found in fertilizers are nitrogen, phosphorus, and potassium in different proportions. A lack of or scarcity of such elements in many soils limits the productivity of the plants. However, the increase in the production of certain plants through the addition of fertilizers results in a reduction in plant biodiversity in the treated area [41,42]. The reduction in plant biodiversity due to soil fertilization is normally associated with increases in aboveground production [43]. This phenomenon can be explained with three different theories: (i) the light asymmetry theory, which is related to the delayed growth of slower-growing plants [44].; (ii) the total competition hypothesis, which 
suggests a belowground competition in addition to the aboveground competition [45]; (iii) the litter hypothesis, which points to the fact that increased production of certain plants produces an increase in litter production of these species, inhibiting the germination of seeds from other species [46].

On the basis of a meta-analysis of 115 experiments, a reduction in biodiversity is observed with the addition of nitrogen. This reduction is more remarkable when $\mathrm{NH}_{4}{ }^{+}$is used than when $\mathrm{NO}_{3}$ is used as a fertilizer. This loss of species richness due to nitrogen addition has been shown to be more significant in warmer environments, resulting in a greater loss of nitrogen-sensitive species, such as legumes and non-vascular plants [47]. In addition, several studies show a reduction in species richness after the addition of phosphorus and other nutrients as a fertilizer [47].

The reduction in plant biodiversity due to fertilizer addition also results in a reduction in the biodiversity of the soil microbiota (at both the bacterial and fungal levels) [48]. Moreover, the addition of these fertilizers affects carbon availability, $\mathrm{pH}$, and soil osmolarity. Furthermore, it generates toxicity due to the presence of certain ions, resulting in a reduction in the abundance of Acidobacteria and Nitrospirae and a slight increase in Actinobacteria and Firmicutes. This reduction in microbial diversity in response to nitrogen addition is associated with a reduction in microbial biomass [49].

The traditional use of fertilizers of animal origin also alters the microbial composition. This is associated with both the way in which the elements are found and the incorporation of microorganisms from the intestine of the animals [50,51].

\subsection{Herbicides and Other Pesticides}

Herbicides are chemical molecules designed to reduce the growth of unwanted plants, and thus, they promote the productivity of the plants used in agriculture. Herbicides normally have different weed targets (see Beffa et al. (2019) for a recent review) [52] and have a high oxidative potential due to the high number of electronegative residues in their structure, including chlorine, phosphoric acid, hydroxide, oxygen, sulfonyl, amines, etc. This increased oxidative potential and other molecular interactions also affect non-target organisms, including other photosynthetic organisms, shredders, primary and secondary predators, and decomposers, including various soil microorganisms, resulting in a general increase in members of the Actinobacteria phylum and other herbicide-tolerant bacteria [53]. In addition, microbial communities are enriched with microorganisms with the metabolic machinery to degrade and consume such chemicals [54]. Agriculture also makes use of other chemical molecules to kill fungi, nematodes, insects, and rodents that affect food production. Again, such molecules alter the biodiversity of the area in which they are used and have a particularly profound effect on soil microorganisms $[55,56]$.

\subsection{Other Aspects of the Green Revolution}

A huge increase in the use of chemical fertilizers, herbicides, and pesticides coincided with the use of non-renewable fuel-driven machinery, highly efficient controlled watering systems, and specific plant varieties with higher yields, all of which tripled global crop production from 1950 in a process termed the Green Revolution. However, the outstanding increase in crop production associated with the Green Revolution had serious environmental impacts. These impacts include a marked increase in greenhouse gas emissions, a threatening dependence on fossil fuels, conflicts associated with water use and sovereignty, soil salinization, a remarkable reduction in biodiversity, and substantial damage to human health and the environment [57]. These effects have intensified due to the increased demand for meat on a global scale and the production of crops for biofuel $[58,59]$. Many researchers point to global climate change, water eutrophication, and soil salinization as the main consequences of the Green Revolution, all of which cause tremendous biodiversity losses $[60,61]$. Therefore, alternatives to the current agriculture techniques associated with the Green Revolution are needed in order to prevent a massive reduction in biodiversity. An alternative method with which to tackle the increased food 
demand is internal ecosystem engineering, which can be seen as an alternative to the external manipulation of ecosystems associated with the Green Revolution. Brender et al. coined the term Underground Revolution to denote a method that provides the appropriate combination of organisms to the soil according to the plant requirements for growth [62].

\section{Future Prospects and Concluding Remarks}

Microorganisms can be used to promote plant growth by fixing atmospheric nitrogen and solubilizing inorganic phosphate; they can be used as alternatives to pesticides for the control of insects and other pathogens and can even promote plant growth in saline and arid soils [63-65]. The detrimental effects associated with various agricultural practices can be counterbalanced by the use of certain microorganisms. The use of biostimulants has been proposed as a method to reestablish the environment after floods and irrigation, fires, tilling, and plowing. Moreover, they are currently used as an alternative to chemical fertilizers, herbicides, and other pesticides. Biostimulants offer an environmentally friendly technique to reduce the damaging effects associated with these chemicals.

Several studies demonstrate that the addition of Rhizophagus irregularis or Glomus mosseae, both types of arbuscular mycorrhizal fungi (AMF), facilitates plant growth by enhancing the absorption of nutrient elements, such as phosphorous, and by promoting proline accumulation and improving root architecture under flooding conditions [66,67]. Furthermore, PGPB, such as Pseudomonas fluorescens $\mathrm{REN}_{1}$ and Pseudomonas putida UW4, have been used to protect plants such as Rumex palustris from floods owing to their ability to promote root elongation in plants through the activity of ACC deaminase and by reducing the production of indole-3-acetic acid (IAA) under constant flooded conditions [68,69]. In addition to microorganisms, other molecules, known as biostimulants, can promote plant growth by altering plant hormonal profiles [70]. Similar effects have been observed when applying various types of biostimulants based on fermented vegetable extracts and seaweed together with phytohormones. They provide protection for plants from floods but also improve soil microbial biodiversity by increasing the activity of soil enzymes involved in nitrogen fixation, phosphorus solubilization, the production of organic substances, and oxidation-reduction processes [71].

Soil toxicity resulting from fires used for agricultural practices can be reduced by AMF, PGPR, and other biostimulants. A recent study by Turjaman and Osaki (2021) described the use of AMF, ectomycorrhizal (ECM) fungi, and PGPR to restore soils affected by fires [72]. These strains reduce the toxicity of soils by transforming the pollutants into less toxic forms, regulating the bioavailability of certain molecules by producing certain chelators, and by releasing certain extracellular enzymes and hormones. Several PGPR belonging to the genera Arthrobacter, Pseudomonas, and Bacillus have been effectively used for the remediation of heavy metals, aromatic hydrocarbons, and to restore soil $\mathrm{pH}$ in soils affected by fires. Various bacteria also enhance the efficiency of bioremediation by promoting plant growth, alleviating pollutant phytotoxicity, improving ecosystem resilience, altering the bioavailability of pollutants in soil, and increasing translocation within plants [73,74]. Deforestation resulting from fires reduces evapotranspiration, which translates into increased aridity and desertification. The stress produced by water scarcity can be reduced by using certain microorganisms such as Microbacterium sp. 3J1 [75].

Other biostimulants have been used to reduce the detrimental effect associated with pollutants such as herbicides and pesticides. These dangerous chemicals can be replaced by biostimulants, which are widely used as biological control agents to antagonize and suppress destructive entomopathogens and bacterial and fungal pathogens in several ways [76]. The use of chemical fertilizers, herbicides, and pesticides also increases soil salinity, which can be alleviated by using certain microorganisms such as various species of the genus Dermacoccus [77].

It is important to guarantee that the introduction of biostimulants does not have a negative impact on the environment or human health. Vílchez et al. proposed a combination of bioassays to numerically determine the biosafety of bacterial strains that are intended to be released as biostimulants [78]. The European Union has recently regulated the use of 
bacteria as biostimulants in Regulation (EU) 2019/1009. However, the criteria established for shortlisting microbes that can be used are, in our opinion, inappropriate, as they are based solely on taxonomical criteria, as described by Barros-Rodríguez et al. [79]. In addition, appropriate assays should be incorporated to guarantee the efficiency of microbes used as biostimulants, including heat-inactivated microorganisms as controls, and these should be coupled with a proper analysis of the biostimulant expiration date [79].

In conclusion, the addition of certain biostimulants, in combination with appropriate management practices, would increase biodiversity in agricultural soils, providing specific functions and enhancing the overall ecosystem, which is of particular relevance in light of the increasing demand for food.

Author Contributions: Investigation, A.B.-R. and P.R.; writing—original draft preparation, A.B.-R. and M.M.; conceptualization, W.P.-a. and K.L.; funding acquisition, supervision, and writingreview and editing M.M. and W.P.-a. All authors have read and agreed to the published version of the manuscript.

Funding: This study was funded by the Spanish Ministry for Economy and Competitiveness and the European Union, within the context of the research projects CTM2017-84332-R, and CGL2017-91737EXP, and by the Andalusian Regional Government under the aegis of research project P11-RNM-7844 and P18-RT-976. W.P.-a., K.L., and P.R. are also grateful for partial support by Chiang Mai University and the European Union through the Erasmus+ program.

Institutional Review Board Statement: Not applicable.

Informed Consent Statement: Not applicable.

Data Availability Statement: Data sharing does not apply to this article as no datasets were generated or analyzed during the current study.

Acknowledgments: We thank Nieves Escolano and Ginés González de Patto for their technical support and VitaNtech Biotechnology for donation of materials and administrative support.

Conflicts of Interest: The authors declare no conflict of interest.

\section{References}

1. Johnson, C.N.; Balmford, A.; Brook, B.W.; Buettel, J.C.; Galetti, M.; Guangchun, L.; Wilmshurst, J.M. Biodiversity losses and conservation responses in the Anthropocene. Science 2017, 356, 270-275. [CrossRef] [PubMed]

2. Turcotte, M.M.; Araki, H.; Karp, D.S.; Poveda, K.; Whitehead, S.R. The eco-evolutionary impacts of domestication and agricultural practices on wild species. Philos. Trans. R. Soc. B Biol. Sci. 2017, 372, 20160033. [CrossRef] [PubMed]

3. Milla, R.; Osborne, C.P.; Turcotte, M.M.; Violle, C. Plant domestication through an ecological lens. Trends Ecol. Evol. 2015, 30, 463-469. [CrossRef] [PubMed]

4. Maddison, A. The World Economy. A Millenial Perspective; OECD Publishing: Paris, France, 2001; ISBN 92-64-18998-X.

5. Nielsen, R.W. Growth of the world population in the past 12,000 years and its link to the economic growth. J. Econ. Bibliogr. 2016, 3, 1-12. [CrossRef]

6. Ramankutty, N.; Evan, A.T.; Monfreda, C.; Foley, J.A. Farming the planet: 1. Geographic distribution of global agricultural lands in the year 2000. Glob. Biogeochem. Cycles 2008, 22. [CrossRef]

7. Kehoe, L.; Romero-Muñoz, A.; Polaina, E.; Estes, L.; Kreft, H.; Kuemmerle, T. Biodiversity at risk under future cropland expansion and intensification. Nat. Ecol. Evol. 2017, 1, 1129-1135. [CrossRef]

8. Best, J. Anthropogenic stresses on the world's big rivers. Nat. Geosci. 2018, 12, 7-21. [CrossRef]

9. Macklin, M.G.; Lewin, J. The rivers of civilization. Quat. Sci. Rev. 2015, 114, 228-244. [CrossRef]

10. González Macé, O.; Steinauer, K.; Jousset, A.; Eisenhauer, N.; Scheu, S. Flood-induced changes in soil microbial functions as modified by plant diversity. PLoS One 2016, 11, 1-15. [CrossRef]

11. Hefting, M.; Clement, J.-C.; Dowrick, D.; Cosandey, A.; Bernal, S.; Cimpian, C.; Tatur, A.; Burt, T.; Pinay, G. Water table elevation controls on soil nitrogen cycling in riparian wetlands along a European climatic gradient. Biogeochemistry 2004, 67, 113-134. [CrossRef]

12. Lockaby, B.G.; Murphy, A.L.; Somers, G.L. Hydroperiod Influences on Nutrient Dynamics in Decomposing Litter of a Floodplain Forest. Soil Sci. Soc. Am. J. 1996, 60, 1267-1272. [CrossRef]

13. Unger, I.M.; Kennedy, A.C.; Muzika, R.-M. Flooding effects on soil microbial communities. Appl. Soil Ecol. 2009, 42, 1-8. [CrossRef]

14. Wagner, D.; Eisenhauer, N.; Cesarz, S. Plant species richness does not attenuate responses of soil microbial and nematode communities to a flood event. Soil Biol. Biochem. 2015, 89, 135-149. [CrossRef] 
15. Sorensen, P.O.; Germino, M.J.; Feris, K.P. Microbial community responses to 17 years of altered precipitation are seasonally dependent and coupled to co-varying effects of water content on vegetation and soil C. Soil Biol. Biochem. 2013, 64, 155-163. [CrossRef]

16. Zhang, Y.; Dai, J.; Wang, R.; Zhang, J. Effects of long-term sewage irrigation on agricultural soil microbial structural and functional characterizations in Shandong, China. Eur. J. Soil Biol. 2008, 44, 84-91. [CrossRef]

17. Whitlock, C.; Colombaroli, D.; Conedera, M.; Tinner, W. Land-use history as a guide for forest conservation and management. Conserv. Biol. 2017, 32, 84-97. [CrossRef]

18. Potapov, P.; Hansen, M.C.; Laestadius, L.; Turubanova, S.; Yaroshenko, A.; Thies, C.; Smith, W.; Zhuravleva, I.; Komarova, A.; Minnemeyer, S.; et al. The last frontiers of wilderness: Tracking loss of intact forest landscapes from 2000 to 2013. Sci. Adv. 2017, 3, e1600821. [CrossRef]

19. Certini, G. Effects of fire on properties of forest soils: A review. Oecologia 2005, 143, 1-10. [CrossRef]

20. Choromanska, U. Microbial activity and nitrogen mineralization in forest mineral soils following heating: Evaluation of post-fire effects. Soil Biol. Biochem. 2002, 34, 263-271. [CrossRef]

21. Cobo-Díaz, J.F.; Fernández-González, A.J.; Villadas, P.J.; Robles, A.B.; Toro, N.; Fernández-López, M. Metagenomic assessment of the potential microbial nitrogen pathways in the rhizosphere of a Mediterranean forest after a wildfire. Microb. Ecol. 2015, 69, 895-904. [CrossRef]

22. Prendergast-Miller, M.T.; de Menezes, A.B.; Macdonald, L.; Toscas, P.; Bissett, A.; Baker, G.; Farrell, M.; Richardson, A.E.; Wark, T.; Thrall, P.H. Wildfire impact: Natural experiment reveals differential short-term changes in soil microbial communities. Soil Biol. Biochem. 2017, 109, 1-13. [CrossRef]

23. Sun, H.; Santalahti, M.E.; Pumpanen, J.; Köster, K.; Berninger, F.; Raffaello, T.; Asiegbu, F.O.; Heinonsalo, J. Bacterial community structure and function shift across a northern boreal forest fire chronosequence. Sci. Rep. 2016, 6, 32411. [CrossRef] [PubMed]

24. Narváez-Reinaldo, J.J.; Barba, I.; González-López, J.; Tunnacliffe, A.; Manzanera, M. Rapid Method for Isolation of DesiccationTolerant Strains and Xeroprotectants. Appl. Environ. Microbiol. 2010, 76, 5254-5262. [CrossRef] [PubMed]

25. Malhi, S.; Kutcher, H. Small grains stubble burning and tillage effects on soil organic $\mathrm{C}$ and N, and aggregation in northeastern Saskatchewan. Soil Tillage Res. 2007, 94, 353-361. [CrossRef]

26. Romasanta, R.R.; Sander, B.O.; Gaihre, Y.K.; Alberto, M.C.; Gummert, M.; Quilty, J.; Nguyen, H.; Castalone, A.G.; Balingbing, C.; Sandro, J.; et al. How does burning of rice straw affect $\mathrm{CH}_{4}$ and $\mathrm{N}_{2} \mathrm{O}$ emissions? A comparative experiment of different on-field straw management practices. Agric. Ecosyst. Environ. 2017, 239, 143-153. [CrossRef]

27. Raheem, A.; Sajid, M.; Iqbal, M.S.; Aslam, H.; Bilal, M.; Rafiq, F. Microbial inhabitants of agricultural land have potential to promote plant growth but they are liable to traditional practice of wheat (T. aestivum L) straw burning. Biocatal. Agric. Biotechnol. 2019, 18, 101060. [CrossRef]

28. Jangid, K.; Williams, M.A.; Franzluebbers, A.; Sanderlin, J.S.; Reeves, J.H.; Jenkins, M.B.; Endale, D.M.; Coleman, D.; Whitman, W. Relative impacts of land-use, management intensity and fertilization upon soil microbial community structure in agricultural systems. Soil Biol. Biochem. 2008, 40, 2843-2853. [CrossRef]

29. Lal, R. Enhancing ecosystem services with no-till. Renew. Agric. Food Syst. 2013, 28, 102-114. [CrossRef]

30. Groenigen, J.W.; Lubbers, I.M.; Vos, H.M.J.; Brown, G.G.; De Deyn, G.B.; van Groenigen, K.J. Earthworms increase plant production: A meta-analysis. Sci. Rep. 2016, 4, 6365. [CrossRef]

31. Scheu, S. Effects of earthworms on plant growth: Patterns and perspectives: The 7th international symposium on earthworm ecology · Cardiff · Wales · 2002. Pedobiologia 2003, 47, 846-856. [CrossRef]

32. Blouin, M.; Hodson, M.; Delgado, E.A.; Baker, G.L.; Brussaard, L.; Butt, K.; Dai, J.; Dendooven, L.; Peres, G.; Tondoh, J.E.; et al. A review of earthworm impact on soil function and ecosystem services. Eur. J. Soil Sci. 2013, 64, 161-182. [CrossRef]

33. Groenigen, J.W.V.; Groenigen, K.J.V.; Koopmans, G.F.; Stokkermans, L.; Vos, H.M.J.; Lubbers, I.M. How fertile are earthworm casts? A meta-analysis. Geoderma 2019, 338, 525-535. [CrossRef]

34. Briones, M.J.I.; Schmidt, O. Conventional tillage decreases the abundance and biomass of earthworms and alters their community structure in a global meta-analysis. Glob. Change Biol. 2017, 23, 4396-4419. [CrossRef]

35. Domínguez, A.; Bedano, J.C. Earthworm and Enchytraeid Co-occurrence Pattern in Organic and Conventional Farming. Soil Sci. 2016, 181, 148-156. [CrossRef]

36. Zuber, S.; Villamil, M.B. Meta-analysis approach to assess effect of tillage on microbial biomass and enzyme activities. Soil Biol. Biochem. 2016, 97, 176-187. [CrossRef]

37. Álvaro-Fuentes, J.; Morell, F.; Madejón, E.; Lampurlanés, J.; Arrúe, J.; Cantero-Martínez, C. Soil biochemical properties in a semiarid Mediterranean agroecosystem as affected by long-term tillage and N fertilization. Soil Tillage Res. 2013, 129, 69-74. [CrossRef]

38. Navarro-Noya, Y.E.; Gómez-Acata, S.; Montoya-Ciriaco, N.; Rojas-Valdez, A.; Suárez-Arriaga, M.C.; Valenzuela-Encinas, C.; Jiménez-Bueno, N.; Verhulst, N.; Govaerts, B.; Dendooven, L. Relative impacts of tillage, residue management and crop-rotation on soil bacterial communities in a semi-arid agroecosystem. Soil Biol. Biochem. 2013, 65, 86-95. [CrossRef]

39. Verzeaux, J.; Roger, D.; Lacoux, J.; Nivelle, E.; Adam, C.; Habbib, H.; Hirel, B.; Dubois, F.; Tetu, T. In Winter Wheat, No-Till Increases Mycorrhizal Colonization thus Reducing the Need for Nitrogen Fertilization. Agronomy 2016, 6, 38. [CrossRef]

40. Clark, C.M.; Tilman, D. Loss of plant species after chronic low-level nitrogen deposition to prairie grasslands. Nature 2008, 451, 712-715. [CrossRef] 
41. Dickson, T.L.; Gross, K.L. Plant community responses to long-term fertilization: Changes in functional group abundance drive changes in species richness. Oecologia 2013, 173, 1513-1520. [CrossRef]

42. Suding, K.N.; Collins, S.; Gough, L.; Clark, C.; Cleland, E.E.; Gross, K.L.; Milchunas, D.G.; Pennings, S. Functional- and abundance-based mechanisms explain diversity loss due to N fertilization. Proc. Natl. Acad. Sci. USA 2005, 102, 4387-4392. [CrossRef] [PubMed]

43. DeMalach, N.; Zaady, E.; Weiner, J.; Kadmon, R. Size asymmetry of resource competition and the structure of plant communities. J. Ecol. 2016, 104, 899-910. [CrossRef]

44. Rajaniemi, T.K. Explaining productivity-diversity relationships in plants. Oikos 2003, 101, 449-457. [CrossRef]

45. Foster, B.L.; Gross, K.L. Species richness in a successional grassland: Effects of nitrogen enrichment and plant litter. Ecology 1998, 79, 2593-2602. [CrossRef]

46. Midolo, G.; Alkemade, R.; Schipper, A.M.; Benítez-López, A.; Perring, M.P.; De Vries, W. Impacts of nitrogen addition on plant species richness and abundance: A global meta-analysis. Glob. Ecol. Biogeogr. 2018, 28, 398-413. [CrossRef]

47. Fay, P.A.; Prober, S.M.; Harpole, W.S.; Knops, J.M.H.; Bakker, J.D.; Borer, E.T.; Lind, E.M.; MacDougall, A.S.; Seabloom, E.W.; Wragg, P.D.; et al. Grassland productivity limited by multiple nutrients. Nat. Plants 2015, 1, 15080. [CrossRef]

48. Wang, C.; Liu, D.; Bai, E. Decreasing soil microbial diversity is associated with decreasing microbial biomass under nitrogen addition. Soil Biol. Biochem. 2018, 120, 126-133. [CrossRef]

49. Kumar, U.; Nayak, A.K.; Shahid, M.; Gupta, V.V.; Panneerselvam, P.; Mohanty, S.; Kaviraj, M.; Kumar, A.; Chatterjee, D.; Lal, B.; et al. Continuous application of inorganic and organic fertilizers over 47 years in paddy soil alters the bacterial community structure and its influence on rice production. Agric. Ecosyst. Environ. 2018, 262, 65-75. [CrossRef]

50. Wang, L.; Yang, F.; Yaoyao, E.; Yuan, J.; Raza, W.; Huang, Q.; Shen, Q. Long-Term Application of Bioorganic Fertilizers Improved Soil Biochemical Properties and Microbial Communities of an Apple Orchard Soil. Front. Microbiol. 2016, 7, 1893. [CrossRef]

51. Beffa, R.; Menne, H.; Köcher, H. Herbicide Resistance Action Committee (HRAC): Herbicide classification, resistance evolution, survey, and resistance mitigation activities. In Modern Crop Protection Compounds, Volume 3: Insecticides, Third, Completely Revised and Enlarged Edition; Wiley-VCH Verlag GmbH \& Co. KGaA: Weinheim, Germany, 2019; pp. 5-32. [CrossRef]

52. García-Delgado, C.; Vicente, V.B.; Marín-Benito, J.; Igual, J.M.; Sánchez-Martín, M.J.; Rodríguez-Cruz, M.S. Influence of different agricultural management practices on soil microbial community over dissipation time of two herbicides. Sci. Total Environ. 2018, 646, 1478-1488. [CrossRef]

53. Wang, Y.; Hatt, J.K.; Tsementzi, D.; Rodriguez-R, L.M.; Perez, C.A.R.; Weigand, M.R.; Kizer, H.; Maresca, G.; Krishnan, R.; Poretsky, R.; et al. Quantifying the Importance of the Rare Biosphere for Microbial Community Response to Organic Pollutants in a Freshwater Ecosystem. Appl. Environ. Microbiol. 2017, 83, e03321-16. [CrossRef] [PubMed]

54. Gallego, S.; Devers-Lamrani, M.; Rousidou, K.; Karpouzas, D.G.; Martin-Laurent, F. Assessment of the effects of oxamyl on the bacterial community of an agricultural soil exhibiting enhanced biodegradation. Sci. Total Environ. 2018, 651, 1189-1198. [CrossRef]

55. Mulla, S.I.; Ameen, F.; Talwar, M.P.; Eqani, S.A.M.A.S.; Bharagava, R.N.; Saxena, G.; Tallur, P.N.; Ninnekar, H.Z. Organophosphate pesticides: Impact on environment, toxicity, and their degradation. In Bioremediation of Industrial Waste for Environmental Safety; Springer: Singapore, 2020; pp. 265-290. [CrossRef]

56. Pingali, P.L. Green Revolution: Impacts, limits, and the path ahead. Proc. Natl. Acad. Sci. USA 2012, 109, 12302-12308. [CrossRef] [PubMed]

57. Horlings, L.; Marsden, T. Towards the real green revolution? Exploring the conceptual dimensions of a new ecological modernisation of agriculture that could 'feed the world'. Glob. Environ. Chang. 2011, 21, 441-452. [CrossRef]

58. Manzanera, M.; Molina-Muñoz, M.L.; González-López, J. Biodiesel: An alternative fuel. Recent Pat. Biotechnol. 2008, 2, 25-34. [CrossRef]

59. Tilman, D.; Fargione, J.; Wolff, B.; D’Antonio, C.; Dobson, A.; Howarth, R.; Schindler, D.; Schlesinger, W.H.; Simberloff, D.; Swackhamer, D. Forecasting Agriculturally Driven Global Environmental Change. Science 2001, 292, 281-284. [CrossRef]

60. Banerjee, S.; Walder, F.; Büchi, L.; Meyer, M.; Held, A.Y.; Gattinger, A.; Keller, T.; Charles, R.; van der Heijden, M.G.A. Agricultural intensification reduces microbial network complexity and the abundance of keystone taxa in roots. ISME J. 2019, 13, 1722-1736. [CrossRef]

61. Bender, S.F.; Wagg, C.; van der Heijden, M.G. An Underground Revolution: Biodiversity and Soil Ecological Engineering for Agricultural Sustainability. Trends Ecol. Evol. 2016, 31, 440-452. [CrossRef]

62. Colla, G.; Rouphael, Y.; Canaguier, R.; Svecova, E.B.; Cardarelli, M. Biostimulant action of a plant-derived protein hydrolysate produced through enzymatic hydrolysis. Front. Plant. Sci. 2014, 5, 448. [CrossRef]

63. Vílchez, J.I.; Fontana, C.G.; Román-Naranjo, D.; González-López, J.; Manzanera, M. Plant Drought Tolerance Enhancement by Trehalose Production of Desiccation-Tolerant Microorganisms. Front. Microbiol. 2016, 7, 1577. [CrossRef]

64. Caruso, G.; De Pascale, S.; Cozzolino, E.; Giordano, M.; El-Nakhel, C.; Cuciniello, A.; Cenvinzo, V.; Colla, G.; Rouphael, Y. Protein Hydrolysate or Plant Extract-based Biostimulants Enhanced Yield and Quality Performances of Greenhouse Perennial Wall Rocket Grown in Different Seasons. Plants 2019, 8, 208. [CrossRef]

65. Vílchez, J.I.; Navas, A.; Egonzález-López, J.; Arcos, S.C.; Emanzanera, M. Biosafety Test for Plant Growth-Promoting Bacteria: Proposed Environmental and Human Safety Index (EHSI) Protocol. Front. Microbiol. 2016, 6, 1514. [CrossRef] [PubMed] 
66. Bao, X.; Wang, Y.; Olsson, P.A. Arbuscular mycorrhiza under water-Carbon-phosphorus exchange between rice and arbuscular mycorrhizal fungi under different flooding regimes. Soil Biol. Biochem. 2018, 129, 169-177. [CrossRef]

67. Zheng, F.-L.; Liang, S.-M.; Chu, X.-N.; Yang, Y.-L.; Wu, Q.-S. Mycorrhizal fungi enhance flooding tolerance of peach through inducing proline accumulation and improving root architecture. Plant. Soil Environ. 2020, 66, 624-631. [CrossRef]

68. Etesami, H.; Hosseini, H.M.; Alikhani, H.A. Bacterial biosynthesis of 1-aminocyclopropane-1-caboxylate (ACC) deaminase, a useful trait to elongation and endophytic colonization of the roots of rice under constant flooded conditions. Physiol. Mol. Biol. Plants 2014, 20, 425-434. [CrossRef]

69. Ravanbakhsh, M.; Sasidharan, R.; Voesenek, L.A.C.J.; Kowalchuk, G.A.; Jousset, A. ACC deaminase-producing rhizosphere bacteria modulate plant responses to flooding. J. Ecol. 2017, 105, 979-986. [CrossRef]

70. Jardin, P. Plant biostimulants: Definition, concept, main categories and regulation. Sci. Hortic. 2015, 196, 3-14. [CrossRef]

71. Mattarozzi, M.; Di Zinno, J.; Montanini, B.; Manfredi, M.; Marengo, E.; Fornasier, F.; Ferrarini, A.; Careri, M.; Visioli, G. Biostimulants applied to maize seeds modulate the enzymatic activity and metaproteome of the rhizosphere. Appl. Soil Ecol. 2020, 148, 103480. [CrossRef]

72. Turjaman, M.; Osaki, M. The Role of mycorrhizal fungi for supporting aerohydro culture in tropical peatland. In Tropical Peatland Eco-Management; Springer: Singapore, 2021; pp. 285-299. [CrossRef]

73. Pizarro-Tobias, P.; Fernandez, M.; Niqui, J.L.; Solano, J.; Duque, E.; Ramos, J.; Roca, A. Restoration of a Mediterranean forest after a fire: Bioremediation and rhizoremediation field-scale trial. Microb. Biotechnol. 2014, 8, 77-92. [CrossRef]

74. Vilchez, S.; Tunnacliffe, A.; Manzanera, M. Tolerance of plastic-encapsulated Pseudomonas putida KT2440 to chemical stress. Extremophiles 2007, 12, 297-299. [CrossRef]

75. Vílchez, J.I.; Niehaus, K.; Dowling, D.N.; González-López, J.; Manzanera, M. Protection of Pepper Plants from Drought by Microbacterium sp. 3J1 by Modulation of the Plant's Glutamine and $\alpha$-ketoglutarate Content: A Comparative Metabolomics Approach. Front. Microbiol. 2018, 9, 284. [CrossRef] [PubMed]

76. Köhl, J.; Kolnaar, R.; Ravensberg, W.J. Mode of Action of Microbial Biological Control Agents Against Plant Diseases: Relevance Beyond Efficacy. Front. Plant Sci. 2019, 10, 845. [CrossRef] [PubMed]

77. Rangseekaew, P.; Barros-Rodríguez, A.; Pathom-Aree, W.; Manzanera, M. Deep-Sea Actinobacteria Mitigate Salinity Stress in Tomato Seedlings and Their Biosafety Testing. Plants 2021, 10, 1687. [CrossRef] [PubMed]

78. Barros-Rodríguez, A.; Rangseekaew, P.; Lausadee, K.; Pathom-aree, W.; Manzanera, M. Regulatory risks associated with bacteria as biostimulants and biofertilizers in the frame of the European Regulation (EU) 2019/1009. Sci. Total Environ. 2020, 740, 140239. [CrossRef]

79. Owen, D.; Williams, A.P.; Griffith, G.W.; Withers, P.J.A. Use of commercial bio-inoculants to increase agricultural production through improved phosphorus acquisition. Appl. Soil Ecol. 2015, 86, 41-54. [CrossRef] 